\title{
Natural mating of instrumentally inseminated queen bees
}

\author{
J Woyke, Z Jasiński \\ Agricultural University, SGGW, Bee Culture Division, Nowoursynowska 166, \\ Warsaw 02-766, Poland
}

(Received 28 October 1991; accepted 4 March 1992)

\begin{abstract}
Summary - Virgin queens homozygous for the recessive cordovan body color gene were inseminated with semen of cordovan drones. The queens were divided into 4 groups and were treated as follows: 1), inseminated with $8 \mathrm{~mm}^{3}$ of semen; 2), treated with $\mathrm{CO}_{2}$ before insemination with $8 \mathrm{~mm}^{3}$ of semen; 3), inseminated twice with $4 \mathrm{~mm}^{3}$ of semen; and 4), treated twice with $\mathrm{CO}_{2}$, ie before and after insemination with $8 \mathrm{~mm}^{3}$ of semen. Queen excluders were removed from the entrances after the last treatment. Mating nuclei were placed in the apiary with dominant black drones. The number of emerging cordovan and black workers was determined. Of the queens which were only inseminated once, $50 \%$ mated naturally; however, out of those additionally treated once with $\mathrm{CO}_{2}$, only $25 \%$ mated. No queen from the 2 other groups mated naturally. The ratio of wild black progeny originating from queens which also mated naturally was on average $33.4 \%$ for group 1 , and $6.2 \%$ for group 2 . Queens from group 1 additionally mated naturally on average with 3 drones per queen, and those from group 2 with only 1 drone per queen. Double insemination with the same total amount of semen or 2 additional $\mathrm{CO}_{2}$ treatments prevented additional natural mating of instrumentally inseminated queens.
\end{abstract}

natural mating / instrumental insemination / queen bee

\section{INTRODUCTION}

Instrumental insemination assures control over mating of parents in the honey bee. However, Woyke (1963) showed that instrumentally inseminated queens fly out of the hive, and some also mate naturally before they start egg laying. Thus, the control over mating of parents is lost. To prevent this, queen excluders are fixed to the hive entrances until the queens start oviposition. This is inconvenient, especial- ly when queens are introduced into normal colonies. Workers have difficulty carrying out normal activities, such as having free access to the colony, sufficient ventilation and so on.

It would be better if the entrance to the hive could be opened while the instrumentally inseminated queen is introduced into the colony during the period prior to egglaying. Mackensen (1947) showed that $\mathrm{CO}_{2}$ treatment of instrumentally inseminated queens accelerated oviposition. 
Treatment of non-inseminated virgins with $\mathrm{CO}_{2}$ decreased the number of queens' flights (Skowronek, 1976), number of matings (Kaftanoglu and Peng, 1982), and oviposition began 2 days earlier (Lensky and Demter, 1985).

The purpose of this investigation was to work out a method which would prevent natural mating of instrumentally inseminated queens from nuclei without queen excluders. A study was therefore conducted to determine the influence of additional treatment with $\mathrm{CO}_{2}$ or additional instrumental insemination on natural mating of instrumentally inseminated queens.

\section{MATERIAL AND METHODS}

Altogether 52 hybrid Italian queens were reared. The young virgins were introduced into 4-comb Kirchhain trapezoid mating nuclei. Queen excluders were fixed at the entrances of the nuclei. All virgins were homozygous for the recessive cordovan body color gene. They were inseminated with the semen of cordovan drones. Before insemination, the virgins were divided into 4 groups of 12-16 queens each. Virgins in each group were treated differently. However, the first treatment was applied to all virgins when they were 6 days old. Queens in the 4 groups were treated as follows: 1), inseminated with $8 \mathrm{~mm}^{3}$ of semen; 2), first treated with $\mathrm{CO}_{2}$, then after 2 days inseminated with $8 \mathrm{~mm}^{3}$ of semen; 3), first inseminated with $4 \mathrm{~mm}^{3}$ of semen then after 2 days again inseminated with $4 \mathrm{~mm}^{3}$ of semen; and 4), first treated with $\mathrm{CO}_{2}$, then after 2 days inseminated with $8 \mathrm{~mm}^{3}$ of semen and after the next 2 days again treated with $\mathrm{CO}_{2}$. The $\mathrm{CO}_{2}$ treatment lasted $3 \mathrm{~min}$. All queens were released into the nuclei immediately after insemination. Queen excluders were removed from the entrances after the last treatment. Mating nuclei with the cordovan queens were placed in an apiary with dominant black drones. If a cordovan queen, inseminated with semen of cordovan drones, also mated naturally with black drones, she produced black workers in addition to cordovan workers.
An additional group was created for comparison. Four cordovan queens were inseminated with $8 \mathrm{~mm}^{3}$ of semen from cordovan drones. After 2 days, they were also instrumentally inseminated with $8 \mathrm{~mm}^{3}$ of semen from black drones. Queen excluders were not detached from the entrances of nuclei containing these queens.

Sealed combs with emerging workers from all the nuclei were put into isolators in an incubator. The number of emerging cordovan and black workers was determined. In total 40000 workers were examined.

\section{RESULTS}

Table I shows that instrumentally inseminated queens in the first 2 groups only also mated naturally. Of the queens inseminated once with $8 \mathrm{~mm}^{3}$ of semen (group 1). $50 \%$ mated naturally. Of those treated once with $\mathrm{CO}_{2}$ before insemination (group 2), $25 \%$ mated naturally. The $\chi^{2}$ goodnessof-fit test showed that the frequency distribution of the number of instrumentally inseminated queens which in addition mated naturally: the number with no additional natural matings in group $1(8: 8, \Sigma=16)$ differed significantly from that in group 2 $(3: 9=1: 3=4: 12) \chi^{2}$ calc $=5.33>\chi^{2}$ tab 0.05 $=3.84$, LP $=0.021$ (d.f.1). Thus the additional treatment with $\mathrm{CO}_{2}$ reduced the percentage of queens which mated naturally. Double insemination (group 3) eliminated

Table I. Natural mating of instrumentally inseminated queens.

\begin{tabular}{lccc} 
Treatment & $\begin{array}{c}\text { Total } \\
\text { No queens }\end{array}$ & \multicolumn{2}{l}{ Naturally mated } \\
\cline { 3 - 4 } & & No & $\%$ \\
\hline & 16 & 8 & $50^{\text {NS }}$ \\
$8 \mathrm{~mm}^{3}$ & 12 & 3 & $25^{\mathrm{NS}}$ \\
$\mathrm{CO}_{2}+8 \mathrm{~mm}^{3}$ & 12 & 0 & 0 \\
$2 \times 4 \mathrm{~mm}^{3}$ & 12 & 0 & 0 \\
$\mathrm{CO}_{2}+8 \mathrm{~mm}^{3}+\mathrm{CO}_{2}$ & 12 & \\
\hline
\end{tabular}


additional natural mating, despite the fact that queens were inseminated with the same total amount of semen as those in the $\mathrm{CO}_{2}+8 \mathrm{~mm}^{3}$ group. Queens inseminated with $8 \mathrm{~mm}^{3}$ of semen and additionally treated twice with $\mathrm{CO}_{2}$ (group 4), did not mate naturally. In each of the last 2 groups, none of the 12 instrumentally inseminated (II) queens also mated naturally. However, the possibility might arise that the 13th queen in each group would mate, which would represent $7.7 \%$. If both groups of II queens which did not additionally mate naturally are considered together, then the 25th queen represents $4 \%$. Thus, although none of the 24 II queens also mated naturally, the present investigation did not exclude the possibility that $4 \%$ or less would mate if more queens were investigated.

The average ratio of wild black progeny originating from queens which also mated naturally was $33.4 \%$ in group 1 (fig 1 ), and $6.0 \%$ in group 2 (fig 2 ).

The 8 queens inseminated with $8 \mathrm{~mm} 3$ of semen which also mated naturally produced $9-66 \%$ wild progeny (fig 3 ). The 3 previously treated with $\mathrm{CO}_{2}$ produced only $3-11 \%$ wild progeny (fig 4 ). The range as well as the averages presented above show even without statistical calculation that the percentage of wild workers origi-

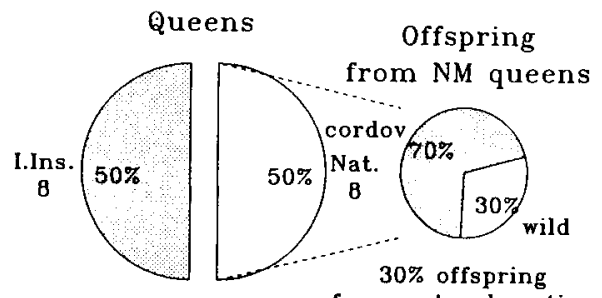

$50 \% 11$ queens mated

from natural matin naturally

Fig 1. Natural mating of queens instrumentally inseminated with $8 \mathrm{~mm}^{3}$ of semen.

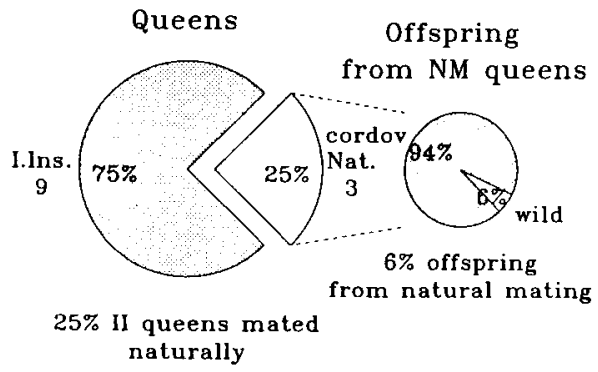

Fig 2. Natural mating of queens treated with $\mathrm{CO}_{2}$ and after two days instrumentally inseminated with $8 \mathrm{~mm}^{3}$ of semen.

nating from additional natural mating was significantly higher in group $1\left(8 \mathrm{~mm}^{3}\right)$ than that in group $2\left(\mathrm{CO}_{2}+8 \mathrm{~mm}^{3}\right)$. Queens in the first group obviously mated additionally, with about 5 times higher number of drones than those in the second group. Thus additional $\mathrm{CO}_{2}$ treatment not only reduced the percentage of queens which also mated naturally, but it also reduced the number of drones with which the queens mated.

The 4 queens inseminated twice with 8 $\mathrm{mm}^{3}$ of semen from cordovan and black drones which could not fly out of the nuclei produced progeny with the following ratio of wild workers: $76.8,62.8,78.5$ and $65.4 \%$.

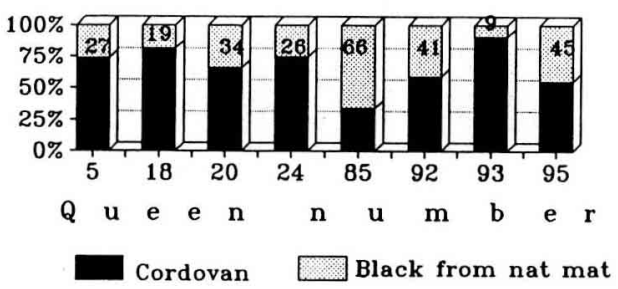

Fig 3. Progeny of 8 queens instrumentally inseminated with $8 \mathrm{~mm}^{3}$ of semen, which also mated naturally. 
Considering the ratio of the number of wild to cordovan progeny, it can be concluded that queens from group 1 also mated naturally probably with about 1-8 drones, and on average with about 5 drones. All 3 queens from group 2, which also mated naturally, probably mated with only 1 drone each.

The ratio of wild progeny in proportion to the whole progeny of all queens in particular groups (additionally naturally mated or not) is presented in figure 5. Additional previous treatment with $\mathrm{CO}_{2}$ of instrumentally inseminated queens reduced the proportion of wild progeny within the total progeny in particular groups from 15\% (group 1) to $1.6 \%$ (group 2).

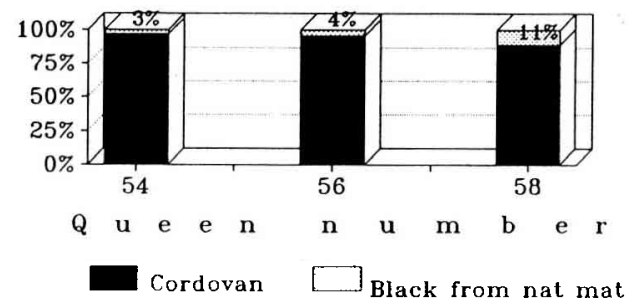

Fig 4. Progeny of 3 queens treated with $\mathrm{CO}_{2}$ and inseminated with $8 \mathrm{~mm}^{3}$ of semen, which also mated naturally.

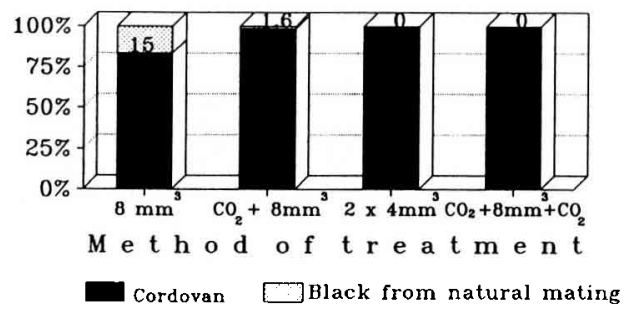

Fig 5. Percentage of progeny from natural mating in ratio to total offspring of all queens in 4 groups.

\section{DISCUSSION AND CONCLUSIONS}

The present investigation confirmed the earlier report of Woyke (1963), according to which some instrumentally inseminated queens fly out of the hive and also mate naturally before they start egg laying. This happens when the queens are not prevented by queen excluders from making mating flights.

Woyke $(1964,1966)$ showed that naturally mated queens which had a lower number and concentration of spermatozoa in the spermatheca undertook additional flights and mated again. Even when queens are instrumentally inseminated with the same amount of semen, a varying number of spermatozoa enter the spermatheca (Woyke, 1960/1962). Thus in this study probably the II queens from groups 1 and 2 which also mated naturally were those which had the lowest number of spermatozoa in their spermatheca after being instrumentally inseminated. However, all the results show that the type of treatment has a greater influence on the behavior of II queens (no queen from groups 3 and 4 also mated naturally), than the number of spermatozoa in their spermatheca, which was probably similar in all groups.

The present investigation showed that an additional treatment with $\mathrm{CO}_{2}$ of instrumentally inseminated queens not only reduced the percentage of queens which also mated naturally, but also the number of drones with which the queens mated. Double insemination with the same total amount of semen or one insemination with 2 additional $\mathrm{CO}_{2}$ treatments eliminated additional natural mating of II queens.

Woyke (1960/1962) has already shown that re-insemination is less effective than the initial insemination. However, in this study more progeny originated from the second insemination than from the first. 
Thus, determination of the probable number of drones with which the queens mated can only be approximate.

In conclusion, further investigation on natural mating of queens instrumentally inseminated in a different manner is still required.

Résumé - Accouplement naturel de reines d'abeilles inséminées artificiellement. Woyke (1963) a montré que des reines d'abeilles inséminées artificiellement quittaient la ruche et que certaines s'accouplaient naturellement avant de commencer à pondre. Pour éviter cela, des grilles à reines sont placées à l'entrée de la ruche jusqu'à ce que celles-ci se mettent à pondre. Le but de cette étude était de mettre au point une méthode qui, sans utiliser de grilles à reines, empêcherait l'accouplement naturel de reines inséminées artificiellement et maintenues dans des nuclei.

Cinquante deux reines vierges homozygotes pour la mutation récessive cordovan (couleur brune du corps) ont été élevées et inséminées avec du sperme de mâles cordovan. Elles ont été divisées en 4 groupes en fonction du traitement : 1 : insémination avec $8 \mathrm{~mm}^{3}$ de sperme, 2 : traitement au $\mathrm{CO}_{2}$ puis insémination avec $8 \mathrm{~mm}^{3}$ de sperme, 3 : double insémination avec 4 $\mathrm{mm}^{3}$ de sperme et $4: 2$ traitements au $\mathrm{CO}_{2}$, l'un avant l'insémination avec $8 \mathrm{~mm}^{3}$ de sperme, l'autre après. Les grilles à reines ont été retirées des entrées après le dernier traitement. Les nuclei de fécondation avec les reines cordovan ont été placés dans un rucher qui contenait des mâles noirs dominants (type sauvage). Le couvain operculé des ruchettes de fécondation a été mis en cagettes en étuve et l'on a dénombré les ouvrières cordovan et les ouvrières noires. Au total 40000 ouvrières ont été examinées.
Les résultats montrent que $50 \%$ des reines du $1^{\text {er }}$ groupe et $25 \%$ des reines du second groupe se sont accouplées naturellement (figs 1 et 2, tableau I). Aucune reine des groupes 3 et 4 ne s'est accouplée naturellement. Le pourcentage de descendance noire des reines qui se sont accouplées en plus naturellement est d'environ $33 \%$ pour le groupe 1 (fig 1) et $6 \%$ pour le groupe 2 (fig 2). Les reines du groupe 1 ont dû s'accoupler avec 5 mâles en moyenne, celles du groupe 2 avec un seul. La double insémination (2 fois 4 $\mathrm{mm}^{3}$ ) et le double traitement au $\mathrm{CO}_{2}$ semblent empêcher les reines inséminées de s'accoupler naturellement par la suite.

reine / insémination artificiellement / accouplement naturel

\section{Zusammenfassung - Natürliche Paar- ung instrumentell besamter Bienenköni- ginnen. Woyke (1963) hat gezeigt, daß in- strumentell besamte (II) Bienenköniginnen ausfliegen und daß manche von ihnen be- gattet werden, bevor sie mit der Eilage be- ginnen. Um das zu verhindern, werden ge- wöhnlich vor dem Flugloch Absperrgitter angebracht, bis die Königinnen mit der Ei- ablage beginnen. Ziel dieser Untersuchung ist die Ausarbeitung einer Methode zur Verhinderung von natürlichen Paarungen von II Königinnen, die in Begattungskästen ohne Absperrgitter gehalten werden.}

Insgesamt wurden 52 Königinnen aufgezogen, die für die Mutation cordovan (braune Körperfarbe) homozygot waren, und mit dem Sperma von cordovanDrohnen besamt. Anschließend wurden sie in folgende vier Gruppen aufgeteilt: 1) Besamung mit $8 \mathrm{~mm}^{3}$ Sperma; 2) Behandlung mit $\mathrm{CO}_{2}$, anschließend Besamung mit $8 \mathrm{~mm}^{3}$ Sperma; 3) zweimalige Besamung mit je $4 \mathrm{~mm}^{3}$ Sperma; 4) Vor und nach der 
Besamung mit $8 \mathrm{~mm}^{3}$ Sperma, zweimalige Behandlung mit $\mathrm{CO}_{2}$. Nach der letzten Behandlung wurden die Absperrgitter vor den Fluglöchern entfernt. Die Begattungsvölkchen mit den cordovan-Königinnen wurden gemeinsam mit Völkern, die dominante schwarze (Wild-) Drohnen enthielten, aufgestellt. Verdeckelte Brut aus den Begattungsvölkchen wurde in Käfigen im Brutschrank gehalten und es wurden die geschlüptten Bienen nach ihrer Farbe sortiert und ausgezählt. Insgesamt wurden 40000 Bienen gezählt.

Die Ergebnisse zeigten, daß sich von den nur einmal besamten Königinnen 50\% auch natürlich gepaart hatten. Von den Königinnen, die zusätzlich noch mit $\mathrm{CO}_{2}$ behandelt worden waren, hatten sich nur $25 \%$ natürlich gepaart (Abb 1 und 2, Tabelle I). Keine einzige Königin aus den beiden anderen Gruppen wurde natürlich begattet. Der Anteil dunkler Nachkommenschaft von Königinnen, die sich zusätzlich auch noch natürlich gepaart hatten, betrug im Durchschnitt 33\% bei Gruppe 1 (Abb 1) und 6\% bei Gruppe 2 (Abb 2). Die Königinnen der Gruppe 1 paarten sich zusätzlich vermutlich mit 5 Drohnen, die Könniginnen von Gruppe 2 mit einem Drohn. Zweimalige Besamung mit derselben Gesamtmenge Sperma oder zwei zusätzliche $\mathrm{CO}_{2}{ }^{-}$ Narkosen scheinen zusätzliche natürliche Paarungen vollständig zu verhindern.

\section{Bienenkönigin / instrumentelle Bes- amung / natürliche Paarung}

\section{REFERENCES}

Kaftanoglu O, Peng $Y(1982)$ Effects of insemination on the initiation of oviposition in the queen honeybee. J Apic Res 21, 3-6

Lensky $Y$, Demter M (1985) Mating flights of the queen honeybee (Apis mellifera) in subtropical climate. Comp Biochem Physiol 81A, 229-241

Mackensen O (1947) Effect of carbon dioxide on initial oviposition of artificially inseminated and virgin queen bees. $J$ Econ Entomol 40, 344-349

Skowronek W (1976) Mating behaviour of honeybee queens after carbon dioxide anesthesia. Pszczel Zesz Nauk 20, 99-115 (in Polish; English summary)

Woyke $J(1960)$ Natural and artificial insemination of queen honey bees. Pszszel Zesz Nauk 4, 183-275 (in Polish). Bee World (1962) 43, 21-25 (English summary)

Woyke $J(1963)$ The behaviour of queens inseminated in a different manner. 19th Int Apic Congr, Prague, 702-703

Woyke J (1964) Causes of repeated mating flights by queen honeybees. $J$ Apic Res 3 , 17-23

Woyke J (1966) Wovon hängt die Zahl der Spermien in der Samenblase der auf natürlichem Wege begatteten Königinnen $a b$ ? Z Bienenforsch 8, 236-247 